\title{
Strategi Penjualan Produk Olahan Singkong (Sampeuin) di Pandemi Covid-19 di Kabupaten Karawang
}

\author{
'Dedi Rianto Rahadi, ${ }^{2}$ Hani Tri Lestari, ${ }^{3}$ Desita Maharani \\ ${ }^{123}$ Program Studi Manajemen, Universitas President
}

\begin{abstract}
Indonesia experienced a drastic economic downturn during the COVID-19 pandemic. The Micro, Small and Medium Enterprises (MSME) sector is the economic sector that is affected. Researchers analyzed from SWOT on the marketing of Sampeuin cassava processed products and determined marketing strategies for Sampeuin cassava processed products in the Covid-19 pandemic. This research was conducted on cassava processing SMEs. In this study, researchers used qualitative research methods. Based on the analysis of the "Sampeuin" cassava processing business using a SWOT (Strength, Weakness, Opportunity, Threat) analysis, there is a use of cassava as a processed food ingredient. Cassava which has many benefits for the human body is processed into "Sampeuin" which is used as a business opportunity in the snack food sector. Since the advent of social media, many business owners have used social media to do business.
\end{abstract}

Keywords: MSME, Marketing Strategy, Cassava

\begin{abstract}
Abstrak
Indonesia mengalami penurunan ekonomi yang drastis selama di tengah pandemi UMKM menjadi sektor ekonomi yang terkena dampaknya. peneliti menganalisis dari SWOT pada pemasaran produk olahan singkong Sampeuin dan Menentukan strategi pemasaran produk olahan singkong Sampeuin di pandemi Covid-19. Penelitian ini dilaksanakan pada UMKM pengolahan singkong. Penelitian ini menggunakan metode penelitian kualitatif. Berdasarkan penelitian terhadap usaha olahan singkong "Sampeuin" dengan menggunakan SWOT analysis (Strength, Weakness, Opportunity, threat) terdapat adanya pemanfaatan dalam menggunakan singkong sebagai bahan olahan makanan. Singkong yang memiliki banyak manfaat pada tubuh manusia ini diolah menjadi "Sampeuin" yang dimana dijadikan sebagai peluang bisnis di bidang makanan ringan. sejak adanya sosial media, banyak pemilik bisnis yang memanfaatkan media sosial untuk berbisnis.
\end{abstract}

Kata Kunci: UMKM, Strategi Pemasaran, Singkong

\begin{tabular}{|c|c|}
\hline DOI & : http://dx.doi.org/10.32503/jmk.v7i1.2111 \\
\hline Sejarah Artikel & $\begin{array}{l}\text { Artikel diterima (29 November 2021); direvisi (15 Desember } \\
\text { 2021); disetujui (30 Desember 2021) }\end{array}$ \\
\hline Korespondensi & : Universitas Presiden, Cikarang, Jawa Barat \\
\hline Email & $\begin{array}{l}\text { : dedi1968@yahoo.com, hani.lestari@ student.president.ac.id, } \\
\text { desita.maharani@student.president.ac.id }\end{array}$ \\
\hline
\end{tabular}


Dedi R. Rahadi, dkk. / Jurnal Manajemen dan Kewirausahaan 7 (1) 2022, 70-82

\section{Pendahuluan}

Virus Covid-19 sudah menyebar di seluruh penjuru negara yang membuat banyak nya masyarakat terkena dampaknya. Dengan adanya pandemi saat ini segala aktivitas sangat dibatasi segala upaya diterapkan diberbagai negara dalam mengurangi penyebaran virus Corona atau Covid-19 salah satunya adalah dengan menjaga jarak antar satu dengan yang lain atau physical distancing. Namun, tampaknya dengan adanya upaya tersebut berdampak pada penurunan ekonomi secara global. Di Indonesia sendiri sudah banyak mengalami penurunan sektor, terutama penurunan ekonomi yang selama ini seharusnya menjadi tumpuan masyarakat. Bagian perekonomian yang terpenting termasuk UMKM ikut terkena dampak dari Pandemi Covid-19. Hal inilah yang menjadi kekhawatiran semua pihak, karena menurunnya sektor penjualan UMKM yang cukup signifikan. Akibat dari penurunan yang terjadi karena pandemi, UMKM mengalami banyak masalah mulai dari penurunan angka penjualan, permodalan, distribusi terhambat, kesulitan ketersediaan bahan baku, dan masih banyaknya penurunan yang dialami oleh pelaku UMKM di indonesia. Harus diakui bahwa UMKM bergerak sebagai ekonomi domestik dan penyerap tenaga kerja saat ini tengah menghadapi adanya penurunan aktivitas yang berakibat pada pengurangan profit atau pendapatan yang signifikan.

Kementerian perencanaan pembangunan nasional (bappenas) melakukan riset mengenai dampak UMKM Indonesia di masa pandemi covid19 dan menemukan hasil yang menyatakan bahwasanya terdapat dua permasalahan utama yang sedang dihadapi para pedagang UMKM di indonesia saat ini. Pertama, masalah keuangan karena tidak ada lagi modal yang didapatkan untuk melanjutkan penjualan saat ini. Sedangkan yang kedua, pasokan atau permintaan pembeli yang terus menerus mengalami penurunan. Terlepas dari dua masalah inti tersebut, terdapat masalah lain nya yaitu para pedagang UMKM yang kurang menguasai platform digital sebagai sarana jual beli yang lebih efisien dan praktis (Soenarso \& Perwitasari, 2021). Terjadinya pandemi covid19 mengakibatkan berkurang nya mobilitas manusia dalam berinteraksi dengan sesama, keadaan ini mengharuskan pedagang untuk bisa memutar otak dan berfikir bagaimana caranya supaya produk yang ditawarkan dapat terjual dengan tidak mengharuskan para konsumen datang dan bertatap muka secara langsung untuk dapat membeli produknya. Dengan menawarkan inovasi pada kemasan sebagai identitas produk dan juga kreativitas dalam menghias barang yang ada di dalam postingan sosial media dapat memikat hati konsumen untuk dapat membeli. Adanya digital sebagai media pemasaran dapat membantu para pelaku UMKM untuk meningkatkan profit yang sempat turun karena dampak dari pandemi Covid-19.

Di dalam sebuah aktivitas perekonomian, sisi kreativitas juga dibutuhkan guna menghidupkan esensi dari ekonomi itu sendiri; sebuah niat yang bisa menghidupkan/menciptakan sebuah ide baru. Ide baru yang nantinya sebagai penyemangat ataupun sebuah alat perbandingan akan suatu ide yang sudah lalu yang mana, tugas nya adalah untuk mempercepat persaingan di dalam aktivitas ekonomi, maupun sektor lainnya. Maka dari itu, dari zaman ke zaman, perubahan akan aktivitas perekonomian pasti selalu ada, entah itu berupa produknya, jasanya, atau alat pembuatnya. Di abad ke $21 \mathrm{ini}$, di Indonesia, sudah banyak daerah yang dilanda Covid-19. Jika kita masih ingin membuat roda perekonomian berputar, 
maka harus ada perubahan dari pelaku ekonomi, itu tidak mudah untuk dijalani di saat seperti ini, tetapi tidak perlu khawatir karena kita sudah mempunyai teknologi yang memadai setidaknya untuk aktivitas perekonomian, dan ilmu Digital Marketing.

Untuk itu, pelaku usaha UMKM yang kami temui ini yang menjual olahan singkong di karawang yang bernama "Sampeuin" dengan owner bernama Vina Aulia. "Samepuin" merupakan produk olahan singkong yang mengandung karbohidrat yang tinggi sehingga cocok menjadi makan pengganti nasi. "Sampeuin" mempunyai tekstur yang lembut membuat semakin lebih nikmat saat dinikmati. Untuk produk "sampeuin" cukup sederhana dan tidak dibuat dalam bentuk kemasana, seperti terlihat pada gambar 1 .

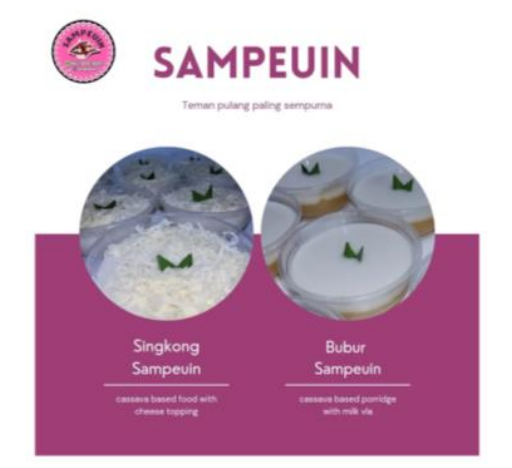

\section{Gambar 1 Produk "sampeuin"}

Produk "sampeuin", dipasarkan secara langsung kepada konsumen dan promosinya masih sangat terbatas. Penggunaan media sosial masih belum optimal hanya terbatas group whatsup (WA) sehingga konsumennya terbatas. Pemasaran yang dijalankan belum dilakukan secara optimal, kondisi ini berbeda dengan pesaing pengrajin singkong yang banyak memanfaatkan strategi pemasaran dengan memanfaatkan sosial media maupun memanfaatkan market place. Contoh pemanfaatan market place oleh pesaing "Sampeuin" dapat dilihat pada gambar 2
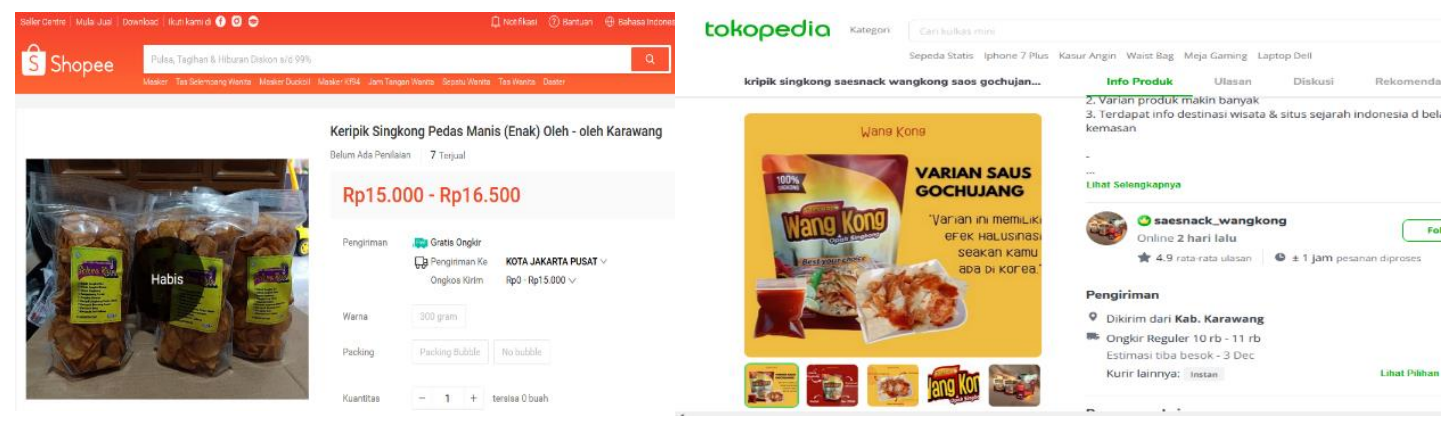

\section{Gambar 2 Pemasaran Pesaing "Sampeuin"}

Untuk meningkatkan pemasaran, pelaku usaha "Sampeuin" dapat menyusun strategi pemasaran produk melalui analisis SWOT (Strength, weakness, opportunity, threats) untuk menarik perhatian konsumen. Dalam berbisnis 
marketing strategi merupakan salah satu unsur paling penting yang harus diperhatikan oleh pebisnis. Hal tersebut berisi strength (kekuatan) merupakan salah satu hal yang dapat memberikan keuntungan atau kelebihan. Weakness atau kelemahan merupakan suatu hal yang dapat menentukan adanya kelemahan yang ada di perusahaan. Selanjutnya adalah opportunity merupakan peluang apa saja yang bisa dimanfaatkan oleh para bidang usaha agar bisa menaikan jumlah penjualan. Lalu threats yang merupakan ancaman-ancaman yang harus dihadapi oleh perusahaan dalam menjalani bisnisnya, dengan adanya ancaman ini yang mungkin bisa menghambat perkembangan perusahaan. Dengan adanya analisis SWOT ini diharapkan bisa menentukan strategi masa depan dalam keberlangsungan bisnis. Dengan menggunakan analisis SWOT, diharapkan perusahaan dapat menganalisis potensi pasar, minat dan peluang penjualan yang dapat dimanfaatkan. Dengan adanya analisis kelemahan ini perusahaan dapat menentukan sebuah jalan keluar atau sebagai pembelajaran agar kedepannya tidak ada kelemahan yang dapat merugikan perusahaan atau pebisnis. Diharapkan dengan contoh kasus pelaku UMKM tersebut akan menjawab semua kesulitan dalam mempertahankan roda perekonomian disaat pandemi pada abad ke 21 di Indonesia ini. Untuk memenuhi target pasar pada masa pandemi Covid-19 pelaku usaha UMKM diharuskan memiliki pemahaman mengenai Digital Marketing. Dengan latar belakang yang kami tulis ini bermaksud untuk melakukan observasi studi kasus tentang bagaimana teknik pemasaran pada UMKM di Masa Pandemi Covid19 dengan studi kasus UMKM Produk Olahan Singkong yang bernama Sampeuin dengan memakai analisis SWOT.

Untuk mendukung permasalahan akan dimasukkan beberapa teori pendukung, yaitu, Strengths (kekuatan), Weaknesses (kelemahan), Opportunities (peluang) dan Threats (ancaman) atau SWOT analisis merupakan salah satu cara perencanaan, perancangan atau sebagai bahan evaluasi sesuatu dengan menganalisis beberapa faktor internal dan juga faktor eksternal. Kekuatan (strengths) dan kelemahan (weaknesses) merupakan faktor internal yang dapat berubah. Peluang (opportunities) dan ancaman (threats) merupakan faktor eksternal yang mampu memberikan pengaruh besar pada suatu hal. misalnya persaingan dan bahan baku. SWOT analisis tersebut tidah hanya untuk individual tetapi bisa digunakan untuk bisnis, suatu organisasi atau perusahaan. SWOT analisis ini bermanfaat untuk membantu individu, organisasi atau bisnis dalam mencapai tujuannya dan sebagai strategi untuk masa depan individu, organisasi dan bisnis. analisis SWOT berperan penting dalam bisnis. analisis ini membantu para pelaku bisnis sebagai bahan evaluasi agar bisnis dapat berkembang lebih baik. Adapun tujuan penelitian adalah menganalisis dari SWOT pada pemasaran produk olahan singkong Sampeuin dan menentukan strategi pemasaran produk olahan singkong Sampeuin di pandemi Covid-19

\section{Metode Penelitian}

Peneliti memilih usaha pengolahan singkong untuk mengetahui bagaimana pelaku usaha melakukan pemasaran produknya dimana pandemi Covid-19. Obyek penelitian adalah pelaku usaha pengolahan singkong dengan merek "Sampeuin" berlokasi di Kabupaten Karawang. Peneliti menggunakan pendekatan kualitatif dalam menganalisis penelitian. Penelitian kualitatif adalah jenis penelitian yang 
mengeksplorasi dan memahami makna di sejumlah individu atau sekelompok orang yang berasal dari masalah sosial. (Creswell: 2016). Pengumpulan data melalui wawancara dengan pelaku usaha yaitu pemilik perusahaan dan konsumen. Tahapan penelitian meliputi : penyusunan rencana penelitian, menentukan lokasi dan subjek pengumpulan data, mengumpulkan data dan analisis data, penyajian dana, penutupan dan penarikan kesimpulan.

Untuk mendukung analisis SWOT, peneliti melakukan beberapa pertanyaan kepada informan yaitu pelaku usaha "sampeuin" dan konsumen.

Adapun pertayaan yang diajukan kepada pelaku usaha, yaitu :

1. Apa kelebihan usaha "sampeuin" jika dibandingkan dengan pesaing ?

2. Apa permasalahan yang sering terjadi khususnya selama masa pandemi dan bagaimana cara mengatasi masalah tersebut?

3. Strategi apa yang dilakukan pelaku usaha "Sampeuin" agar tetap bertahan di masa pandemi dan penjualan dapat ditingkatkan ?

Pertanyaan yang diajukan kepada konsumen meliputi :

1. Darimana anda memperoleh informasi mengenai produk "Sampeuin"?

2. Apakah anda melakukan transaksi pembelian secara online atau secara langsung?

3. Bagaimana dengan harga yang ditawarkan "Sampeuin"?

\section{Hasil dan Pembahasan}

Wawancara yang dilakukan peneliti terhadap pelaku usaha dan konsumen dilakukan secara langsung dengan tetap menjaga protokol kesehatan. Adapun hasil wawaancara tersebut sebagai berikut :

Pelaku usaha:

1. Jawaban informan terhadap pertanyaan 1, sebagai berikut: makanan olahan berbahan dasar singkong ini dapat menjadi makanan pengganti nasi, karena singkong mengandung karbohidrat yang tinggi. Selain itu minat masyarakat terhadap makanan berbahan umbi umbian juga masih tinggi sehingga produk "sampeuin" ini mampu bersaing di pasaran dan dengan adanya inovasi dari "sampeuin" membuat minat masyarakat terhadap makanan ringan dengan harga yang terjangkau jadi tinggi.

2. Jawaban informan terhadap pertanyaan 2, sebagai berikut: Harga bahan baku yang tidak menentu menjadi permasalahan yang sering terjadi. Terkadang harga bahan baku naik dan menurun. Jika terjadi hal ketika harga bahan baku naik, saya mencari bahan baku pengganti yang sejenis atau mengurangi presentase bahan di setiap kemasan dengan tidak menaikkan harga jual produk.

3. Jawaban informan terhadap pertanyaan 3, sebagai berikut: Hal yang di lakukan agar tetap bertahan di tengah pandemi adalah melakukan riset 
konsumen. Membangun komunikasi yang baik pada konsumen juga satu hal untuk memberikan kesan memuaskan pada konsumen. Lalu menerima seluruh kritik dan saran yang diberikan seluruh konsumen guna menjadi bahan evaluasi kedepannya.

Konsumen

1. Jawaban informan terhadap pertanyaan 1, sebagai berikut: Konsumen memperoleh informasi produk "sampeuin" dari social media seperti instagram atau dari status whatsApp penjual, yang memang tempat pelaku usaha untuk memposting atau memasarkan produk "sampeuin" nya.

2. Jawaban informan terhadap pertanyaan 2, sebagai berikut: Konsumen melakukan pembayaran secara langsung, karena jarak penjual masih bisa dijangkau oleh pembeli untuk melakukan pembayaran secara langsung atau COD (Cash on Delivery).

3. Jawaban informan terhadap pertanyaan 3, sebagai berikut: Harga produk "sampeuin" yang di tawarkan oleh penjual adalah Rp 8.000/ cup $200 \mathrm{ml}$.

Dari uraian jawaban informan (pelaku usaha dan konsumen) dapat disimpulkan sebagai berikut :

1. Jenis dan spesifikasi produk.

Sudah banyak sekali produk dari olahan singkong seperti keripik singkong, singkong keju, dan Sampeuin adalah makanan pengganti nasi dengan bahan utama singkong. Dalam pembuatan Sampeuin ini diolah dengan cara yang sangat sederhana atau dalam artian tidak membutuhkan bahan-bahan yang sulit, higienis, serta dijual dengan harga yang terjangkau, maka dari itu dengan hal ini bisa menarik perhatian para konsumen untuk membeli. Bentuk dari produk ini sendiri bertekstur kasar, aroma dan rasa khas singkong. "Sampeuin" ini dibuat dengan direbus terlebih dahulu singkong tersebut, lalu dipotong berbentuk bulat karena mengikuti cup nya yang memakai Thinwall bowl mangkok plastik, cup benning ini besarnya $200 \mathrm{ml}$. Sebelum dimasukan kedalam cup singkong yang sudah di rebus tersebut ditiriskan terlebih dahulu agar cup nya tidak meleleh, setelah didiamkan selama 10 menit singkong tersebut siap dimasukan kedalam cup Thinwall bowl dan bisa di taburkan keju sebagai topping nya. Setelah sudah melewati proses pembungkusan, "Sampeuin" sudah bisa dipasarkan atau dijual ke konsumen.

2. Karakteristik konsumen.

Sasaran usaha "sampeuin" ini adalah remaja dan orang dewasa atau masyarakat yang menyukai olahan singkong. Dengan target konsumen dari remaja hingga dewasa karena pada saat umur remaja sangat menyukai makanan yang mempunyai inovasi baru dan untuk target orang dewasa karena mereka menyukai hal-hal yang praktis dan dengan harga yang terjangkau. 
3. Pemasaran.

Pemasaran adalah aspek terpenting dalam bisnis untuk mengembangkan usahanya di berbagai bidang. usaha "sampeuin" ini bergerak di bidang makanan. pelaku usaha ini memiliki strategi untuk memasarkan produk "sampeuin" atau makanan yang berbahan dasar singkong ini di sosial media. pelaku usaha memfokuskan pemasaran pada sosial media whatsapp. whatsapp saat ini menjadi salah satu sosial media favorite masyarakat karena mudah digunakan untuk berbagi segala informasi. dengan begitu, produk yang ditawarkan akan lebih cepat di lihat oleh semua orang yang terhubung pada whatsapp pelaku usaha sampeuin ini. dengan harga yang ramah di kantong ini juga bisa dinikmati disemua kalangan masyarakat. Pelaku usaha ini juga memasarkan produk di lingkungan sekitar rumahnya di daerah karawang. selain itu, pelaku usaha ini juga menyediakan layanan COD atau yang biasa dikenal cash on delivery khusus untuk konsumen yang berdomisili di daerah karawang. pelaku usaha ini menjualkan produknya dengan sistem PO atau yang biasa kita kenal dengan pre-order yang artinya konsumen harus memesan terlebih dahulu lalu membayar jika barang sudah siap. sistem ini sangat menguntungkan para pelaku usaha karena untuk meminimalisir terjadinya produk yang tidak terjual. sistem ini juga mampu menimbulkan rasa ingin membeli yang tinggi karena biasanya dengan sistem ini hanya menyediakan jumlah yang terbatas.

4. Lingkungan pasar dan pesaing.

Dalam melakukan pemasaran, usaha produk "Sampeuin" tidak mengalami adanya kesulitan, karena banyak nya jaringan yang tersebar di daerah Karawang, yaitu dengan menggunakan reseller sebagai alat memasarkan produk "Sampeuin". Kemudahan penjual produk ini karena banyaknya masyarakat yg memiliki daya minat membeli makanan sejak pandemi covid19 berlangsung. menurut president director mondeles indonesia, 77\% orang Indonesia lebih banyak mengonsumsi camilan atau makanan ringan daripada makanan berat. survei ini juga menandakan bahwa masyarakat indonesia lebih tertarik pada makanan ringan. ini menjadi hasil analisis lingkungan pasar produk "sampeuin".di sekitar tempat tinggal pelaku usaha "sampeuin" ini menjadi salah satu daerah penghasil singkong yang banyak diminati masyarakat. tentunya, bisnis pengolahan berbahan dasar singkong juga sudah tersebar luas di daerah karawang mulai dari keripik singkong hingga getuk. namun, produk "sampeuin" ini jarang ditemui khususnya di kecamatan Rengasdengklok, karawang.

\section{Analisis SWOT}

"Sampeuin" merupakan makanan ringan berbahan dasar singkong yang sudah di bersihkan lalu dipotong dadu dan melalui proses kukus selama 45 menit dengan api sedang untuk menghasilkan singkong yang lembut, lalu disimpan di dalam cup 
plastic berukuran $200 \mathrm{ml}$ saat singkong yang sudah dikukus ditiriskan dan di dinginkan, lalu tambahkan toping di atasnya. Dengan proses pembuatan yang mudah maka pemilik menjualkan produk dengan harga yang sangat terjangkau. Makanan ringan seperti sampeuin ini jenis makanan raingan yang bisa dimakan semua kalangan masyrakat dengan harga yang sangat terjangkau sehingga bisa di beli oleh semua kalangan masyarakat. Berdasarkan analysis SWOT di rumuskan strategi pemasaran produk olahan singkong "sampeuin".

1. Kekuatan

Indonesia sempat mengalami krisis pangan pada tahun 1914 hingga tahun 1918. banyak sekali masyarakat yang menjadikan singkong ini sebagai makanan pokok pengganti nasi dan jagung karena singkong termasuk jenis umbi-umbian yang pasti menyehatkan. sampeu atau yang dalam bahasa indonesia sering disebut dengan singkong ini mengandung kalori dan karbohidrat yang tinggi. sampeu atau singkong ini memiliki banyak manfaat untuk kesehatan tubuh, seperti penambah energi, membantu mencegah terjadinya sembelit, membantu mengendalikan kadar gula darah pada tubuh manusia, dan kaya akan mineral untuk menjaga fungsi jaringan tubuh agar tetap sehat. selain itu, singkong juga mampu membantu menurunkan berat badan. kalori yang ada pada singkong bisa membuat tubuh merasa kenyang lebih lama. oleh karena itu, pelaku usaha "sampeuin" ini menjadikan singkong sebagai bahan baku utama karena singkong adalah makanan yang bisa dinikmati oleh semua kalangan dimasyarakat mulai dari anak-anak hingga orang tua. suatu produk juga membutuhkan kreasi pada kemasan agar menarik para konsumen. hal ini membuat pemilik bisnis "sampeuin" ini membuat beberapa inovasi baru agar kemasan produknya menarik. inovasi inovasi yang dikembangkan ini menjadikan kemasan produk terlihat rapi dan menjaga produk agar tetap higenis hingga ke tanggan pelanggan.

2. Kelemahan

Di kondisi sedang pandemi Covid-19 ini banyak sekali usaha yang mengalami penurunan bahkan sampai gulung tikar karena penurunan pendapatan yang lumayan drastis. Hal ini dirasakan juga oleh usaha olahan singkong "Sampeuin" yang berlokasikan di Rengasdengklok Karawang, usaha ini mengalami adanya penurunan sebesar 30\% dari pendapatan sebelum pandemic, pendapatan sebelum pandemi bisa mencapai $\mathrm{Rp}$ 1.000.000 namun saat pandemi mengalami penurunan menjadi Rp 800.000. Dengan adanya Pandemi Covid-19 banyak sembako yang mengalami kenaikan karena adanya keterbatasan pengiriman yang membuat sembako, kenaikan bahan baku pembuatan "Sampeuin" juga menjadi suatu kelemahan dari usaha "Sampeuin" ini. Untuk mengatasi kelemahan yang dialami oleh usaha "Sampeuin" ini pelaku usaha membuat suatu penawaran 
khusu untuk para konsumennya dan memperluas penyebaran promosi produk seperti melalui media sosial instagram, whatsApp dengan cara memposting foto produknya di halaman media tersebut. Dengan cara ini pelaku usaha berharap bisa menaikan jumlah pendapatan yang sempat selama pandemi dengan menarik pelanggan lebih banyak lagi agar bisa membeli bahan baku tanpa mengurangi persentase dari isi produknya.

3. Peluang

Dengan dilanda pandemi Covid-19 ini pemilik dari usaha olahan singkong "Sampeuin" mencari peluang untuk meningkatkan pendapat yang sempat menurun. Peluang yang dipakai dari usaha ini adalah dengan melakukan riset konsumen, ini berguna untuk menciptakan, memberikan dan mengkomunikasikan nilai-nilai yang dipegang oleh konsumen untuk memuaskan konsumen itu sendiri. Karena pada dasarnya masyarakat senantiasa berubah, baik dari segi selera, keinginan dan kebutuhan. Masyarakat juga lebih pintar dalam memilih suatu produk yang sesuai dengan mereka atau yang tidak sesuai dengan mereka.

4. Ancaman

Harga produk di pasaran tidak bisa di prediksi kapan akan turun dan kapan akan naik. hal ini menjadi ancaman bagi pelaku usaha "sampeuin" ini. karena harga singkong yang tidak pasti di pasaran, pelaku usaha "sampeuin" ini mencari berbagai cara agar mendapatkan singkong yang berkualitas dengan harga yang cukup terjangkau. pelaku usaha "sampeuin" ini melakukan analisis ke beberapa pedagang pasar untuk mencari tahu harga dan kualitas singkong yang akan ia olah. semakin hari, banyak ide kreatif muncul di kepala manusia. mereka memunculkan banyak ide cemerlang untuk mengembangkan dan mengelola bisnis. ini juga menjadi salah satu ancaman bagi pelaku usaha "sampeuin" karena banyaknya makanan yang berbahan dasar singkong dikemas secara menarik. hal ini mendorong kreativitas pemilik bisnis agar terampil dan selalu menampilkan inovasi baru pada produk agar barang yang dijual selalu mendapatkan perhatian para konsumen. akan tetapi, manusia mudah bosan dengan hal yang sudah pernah ia coba atau nikmati. ini menjadi permasalahan juga ketika para konsumen merasa kurang berselera dengan produk yang sudah pernah ia nikmati seperti makanan.

Hasil wawancara bersama dengan pelaku usaha "sampeuin", mereka mengatakan usaha ini memiliki sebuah alasan untuk bisa bertahan di masa pandemi. Dengan jenis produk yang termasuk ke makanan ringan ini membaut masyarakat masih banyak peminatnya. Usaha sampeuin ini juga pernah mengalami penurunan saat masa pandemic seperti harga bahan-bahan yang mengalami kenaikan dan susah nya untuk proses pengiriman produk ke konsumen. Tetapi pemilik mengatasi hal 
tersebut dengan memberikan potongan harga, adanya gratis pembelian dan proses pengiriman produk ke konsumen melalui program COD (Cash on Delivery). Usaha ini dijalankan oleh 1 orang pelaku usaha "sampeuin". Pemilik mengatakan pada awal mula usaha ini berdiri karena adanya keinginan membuat olahan singkong selain hanya di rebus saja, jadi memunculkan ide dengan membuat makanan olahan singkong dengan ada nya toping diatasnya. Dengan harga yang relative murah membuat peminat olahan singkong ini sangat banyak mulai dari anak anak sampai orang dewasa dalam artian bisa di konsumsi oleh semua kalangan. Dengan adanya olahan singkong ini masyrakat jadi mengetahui bahwa olahan singkong ini bisa di kreasikan dengan adanya toping tambahan sebagai rasa baru.

\section{Penyusunan Strategi Pemasaran di Masa Pandemi Covid-19 Pada Produk Sampeuin}

Tentu saja, keluhan pemerintah dan larangan keluar rumah berdampak pada banyak hal, termasuk usaha kecil menengah (UMKM). Pemerintah dalam situs resmi Kementerian Koperasi dan UMKM menyampaikan bahwa penyebaran Covid-19 dapat berdampak langsung terhadap perekonomian, termasuk keberlanjutan koperasi dan usaha kecil menengah (UMKM). Menurunnya aktivitas di luar rumah, dan berkurangnya kepercayaan masyarakat terhadap produk-produk yang tersedia di luar rumah khususnya di bidang memasak. Dengan pandemi Covid 19 di Indonesia belum menurun, namun tidak semua UMKM mengalami penurunan penjualan dan perlu menutup gerainya serta tidak menerapkan berbagai strategi pemasaran untuk bertahan. Dengan hasil penelitian menggunakan analisis SWOT dengan metode kualitatif oleh narasumber yang telah dilakukan usaha "Sampeuin" ini dengan memanfaatkan sosial media sebagai alat pemasaran produknya. Dalam melakukan pemasaran usaha ini mengalami adanya penurunan dikarenakan sulitnya untuk melakukan penjualan dengan sistem COD. Alasan usaha ini melakukan sistem COD karena target penjualan nya masih sekitar daerah karawang yang bisa dilakukan sendiri dengan artian tanpa kurir. Naiknya sembako juga menjadi permasalahan yang harus dialami oleh usaha "Sampeuin" terutama bahan baku dari pengolahan produk ini juga mengalami kenaikan yang cukup signifikan. Maka dari itu dengan adanya kenaikan ini juga pemilik membuat produk dengan isi yang tidak dari biasanya atau bisa dikatakan lain yaitu dikurangi jumlah nya.

Saat melakukan penelitian dengan konsumen dari "Sampeuin", mereka mengatakan merasakan penurunan volume produk yang tidak dari biasanya, harga yang tetap dengan volume yang berkurang membuat konsumen sempat merasa dirugikan. Dengan adanya komplain dari konsumen maka pelaku usaha promosi yaitu seperti jika membeli 1 buah seharga Rp 8.000 jika membeli 2 bisa didapatkan dengan harga Rp 14.000. Dengan menjual melalui sosial media bisa menarik konsumen lebih banyak, maka dengan teknik tersebut yang dilakukan oleh pemilik guna menaikan jumlah pendapatan. 
Selain beberapa strategi yang sudah dijelaskan, pelaku usaha "sampeuin" ini juga membuat promosi menarik seperti, jika membeli dengan jumlah yang banyak akan mendapatkan potongan harga. Dengan teknik ini dapat membuat para konsumen tertarik untuk membeli dengan jumlah yang tidak sedikit dan menjadi keuntungan bagi pelaku usaha. strategi ini sudah umum digunakan para pemilik bisnis agar bisnisnya terus berkembang dan mendapatkan keuntungan yang banyak. Selain promosi usaha "Sampeuin" juga memakai strategi reseller, strategi reseller ini sempat menyita perhatian para pemilik bisnis karena strategi ini bisa membantu menjualkan produk-produk yang kita jual. Semakin banyak yang menjadi reseller produk kita semakin banyak juga keuntungan yang didapatkan. pelaku usaha "sampeuin" ini juga menggunakan strategi satu ini karena dinilai lebih efisien dalam meningkatkan penjualan produk.

\section{Simpulan}

Bisnis UMKM mengalami dampak yang cukup serius akibat pandemi Covid-19. Penyebab penurunan ini disebabkan adanya penurunan jumlah pembeli dan berubahnya frekuensi belanja masyarakat. Salah satu upata yang bisa dilakukan oleh usaha "Sampeuin" ini dalam berwirausaha dalam menarik konsumen dengan konsep pemasaran SWOT. Berdasarkan analisis terhadap usaha olahan singkong "Sampeuin" dengan menggunakan analisis SWOT (Strength, Weakness, Opportunity, threat) terdapat adanya pemanfaatan dalam menggunakan singkong sebagai bahan olahan makanan. Singkong yang memiliki banyak manfaat pada tubuh manusia ini diolah menjadi "Sampeuin" yang dimana dijadikan sebagai peluang bisnis di bidang makanan ringan. proses pengolahan "Sampeuin" yang sederhana dan tidak membutuhkan bahan baku yang rumit menjadi peluang untuk membuka usaha. Walaupun terlihat mudah dalam berbisnis "Sampeuin" ini terdapat kendala yang dialami selama pandemi Covid-19, salah satunya yaitu adanya penurunan pendapatan penjualan. Penurunan penjualan ini dapat dikatakan sebagai ancaman dari usaha tersebut agar tidak gulung tikar, tetapi pemilik berhasil menemukan berbagai solusi untuk usahanya agar tidak gulung tikar. sejak adanya sosial media, banyak pemilik bisnis yang memanfaatkan media sosial untuk berbagai hal dalam bisnisnya. menggunakan media sosial dalam berbisnis dapat menjadi alat untuk mempromosikan produk agar dikenal oleh masyarakat dan menarik minat para konsumen.

Kedepannya produk olahan singkong dapat dilakukan secara online dengan memanfaatkan media social seperti facebook bisnis, Instagram, twiter maupun youtube. Khusus youtube dapat dilakukan dengan membuat konten bagaimana mengolah "Sampeuin" sehingga dapat dilihat konsumen dan menjadi produk pilihan. Selanjutnya penjulan juga dapat dilakukan dengan bekerja sama driver online atau, market place seperti gofood, shopee food, buka lapak dan lain-lain. 


\section{Daftar Pustaka}

Agoes Djatmiko, E. P. (2020). Obstacles and Challenges of Indonesia's Micro, Smaall, and Medium Enterprises (UMKM) In Facing The Covid-19. Jurnal Pendidikan Kewarganegaraan Undiksha, 7.

Ananda Nabilaturrahmah, D. K. (2021). Implementasi Analisis SWOT untuk Menciptakan Strategi Pemasaran Kewirausahaan pada Masa Pandemi. PERMANA: Jurnal Perpajakan, Manajemen, dan Akuntanti , 16.

Arianto, B. (2020). Pengembangan UMKM Digital dimasa Pandemi Covid-19. Jurnal Administrasi Bisnis , 15.

Dalma, M. A. (2021, April 11). Pengertian UMKM: Kriteria, Syarat, Tujuan, Jenis, Contoh. Retrieved from dosenpintar.com: https://dosenpintar.com/pengertian-umkm/\#Tujuan_UMKM

Darwis Agustriyana, N. R. (2021). Bertahan Usaha Pada UMKM di Tengah Pandemic Covid-19. Jurnal Pengabdian Dharma Laksana Mengabdi Untuk Negeri, 7.

Dewi Rengganis, G. W. (2018). Model Bisnis Olahan Singkong pada Usaha Peuyeum Abbas Sawargi Kecamatan Cimenyan Kabupaten Bandung . Jurnal Pemikiran Masyarakat Ilmiah Berwawasan Agribisnis, 18.

Dinda. (2020, March 27). Yuk Ketahui Tahapan Penelitian Kualitatif. Retrieved from TambahPinter.com: https://tambahpinter.com/tahapan-penelitiankualitatif/

Gregorius Rio Alfrian, E. P. (2020). Strategi Uaha, Mikro, Kecil, dan Menengah (UMKM) Bertahan pada Kondisi Pandemic Covid-19 di Indonesia. Seminar Nasional Terapan Riset Inovatif , 8.

Hardilawati, W. L. (2020). Strategi Bertahan UMKM di Tengah Pandemi Covid19. Jurnal Akuntansi dan Ekonomika, 10.

Mas'adah, A. A. (2021). Strategi Pemasaran UMKM di Masa Pandemi Covid: Studi Kasus UMKM di Kawasan Pondok Pesantren Darul Ulum Jombang. Jurnal Bisnis dan Pemasaran Digital, 6.

Mediatama, G. (2021, September 12). Begini upaya UMKM bertahan di tengah pandemi Covid-19. Retrieved from kontan.co.id: https://nasional.kontan.co.id/news/begini-upaya-umkm-bertahan-ditengah-pandemi-covid-19

Moh Khiri Abdi, N. F. (2020). Penyusunan Strategi Pemasaran Islam dalam Berwirausaha di Sektor Ekonomi Kreatif pada Masa Pandemi Covid-19. Jurnal of Islamic Economics and Business, 19.

Praba Indariawati, S. R. (2011). Kajian Strategi Pengembangan Usaha Industri Kripik Singkong Perusahaan PT. Inti Rasa di Bekasi. Manajemen IKM, 6.

Priharto, S. (2019, may 9). Apa Itu Analisis SWOT? Berikut Pengertian, Metode Analisis, dan Contohnya. Retrieved from CPSSOFT: https://cpssoft.com/blog/bisnis/pengertian-analisis-swot/

Raden Achmad Harianto, P. N. (2021). Strategic Digitalization of UMKM Business as an Alternative to Survive the Covid-19 Pandemic. Linguistic and Culture Review, 7. 
Dedi R. Rahadi, dkk. / Jurnal Manajemen dan Kewirausahaan 7 (1) 2022, 70-82

Sari Nurrohmah Yuniarta, L. K. (2021). Strategi Bertahan UMKM Dimasa Pandemi Covid-19 (Studi Kasus di Kota Bengkulu). Jurnal Of Indonesia Management, 7. 